\title{
1. The EU and the growing number of complex security threats
}

\section{Antonina Bakardjieva Engelbrekt, Anna Michalski, Niklas Nilsson and Lars Oxelheim}

In recent years, a sense of danger has become more and more salient in Europe in a number of areas. Some of these perceptions are new and unexpected; others are well-known and have been long debated. They are often held to reflect fear and perceived vulnerability in open and complex societies, yet are also justified in a situation marked by uncertainty in several areas. Europe in the second half of the 2010s seems out of step with the trend prevailing in many other parts of the world, where the liberal order is not seen as the obvious way forward. The fact that a number of political regimes and organized groups around the world do not share liberal values and norms increases the feeling of vulnerability. The perceived or actual threats have furnished a fertile soil for illiberal forces in European countries, and the polarizing impact of such forces on the political climate complicates efforts by the public authorities to confront various perceptions and possibilities of danger. This set of problems has been well-captured by Anthony Giddens (1990) and Ulrich Beck (1992), who speak of the paradox of late modernity. Advanced and affluent societies attempt, by rational means, to manage the risks that arise from social and economic development, thereby engendering the belief that such risks can be parried and neutralized. But those in power often lack the capacity to counter threats of this kind, due to the latter's complexity and/or scope. When this incapacity becomes evident, a deep crisis of confidence results - with unfortunate consequences for democracy.

In the light of the above, the new and threatening situations that have arisen inside and outside the borders of the European Union (EU) are testing in full the ability of the Union to carry out joint crisis management. In Europe's eastern reaches, Russia's aggressive policy in Ukraine, its annexation of the Crimean peninsula and military support to the breakaway republics of Donbas and Luhansk have underlined once again 
the importance of maintaining the military capabilities of European states, and called attention to the centrality of the North Atlantic Treaty Organization (NATO) in guaranteeing their territorial integrity. Nevertheless, Donald J. Trump's victory in the US presidential elections in November 2016 has raised doubts regarding the continued US commitment to European security through NATO. The Union's Member States have agreed on a common policy of sanctions against Russia, but it is clear that the different countries - and their populations - hold varying views on the extent to which Russia poses a security threat. This crisis also has implications for the EU's self-image as an international player that exerts its influence on a normative rather than geopolitical basis. The EU's status as a normative power is challenged by Russia as it has made plain that an important motive for its actions in Ukraine lies in EU policies vis-à-vis Europe's eastern regions - despite their focus on trade and socio-economic reform - rather than in a potential expansion of NATO. Whether Russia's opposition to increasing Western influence in neighbouring areas reflects an honest position, or whether instead it represents an opportunistic pretext for its policy towards Ukraine and Russia's near-abroad, the crisis has highlighted the limited understanding that Russia and the EU's Member States have for the worldview of the other. It has also resulted in a setback for socialization and the spreading of norms as the EU's key foreign policy instrument.

A harsh and prolonged crisis of an entirely different kind played out during the spring and summer of 2015, when the sovereign debt crisis in Greece reached its peak. Extending into the subsequent years, the crisis put that country at risk of leaving the euro, and raised the ultimate prospect of the disintegration of the European Monetary Union (EMU). This crisis illustrated very clearly the substantial differences in prosperity and economic-political structure that exist between the EU's northern and southern Member States. The hope was thereby extinguished that monetary integration on its own would lead to economic convergence across the Eurozone. Instead, divisions arose between richer and poorer countries within the Eurozone about how far fiscal solidarity between them ought to extend.

In the autumn of 2015, furthermore, the EU faced the greatest challenge in its history when a humanitarian crisis within its borders was sparked by large inflows of refugees and migrants from far afield. The crisis had been in the offing for some time as Member States along the Mediterranean, particularly Greece and Italy, have been seeing an ever heavier flow of migrants - under often hazardous conditions - across the Mediterranean for years. This has put a heavy load on facilities in these countries for receiving refugees. However, more recently, there has been a sharp increase in the 
numbers of refugees from war-torn Syria, from the rest of the Middle East, and from Asia and Africa. New roads into Europe were opened through the Balkans. As a result, the situation has developed into a humanitarian crisis - for the whole of Europe - of a kind seldom seen. This crisis has implications far beyond all talk of 'volumes' and reception capacities; it also raises some highly uncomfortable questions about the EU as a political union. How strong is the real will and capacity of EU Member States to act in solidarity with each other and to defend values, such as human rights, which are central to the Union? The row that emerged among the Member States over the distribution of refugees, at the time of writing, is still raging in the EU with little hope of resolving soon. It also has, in its wake, opened a rift between the majority of Member States on one side and the Visegrad countries on the other.

On 13 November 2015 yet another dreadful act of terrorism struck an EU country. Gunmen linked to the Islamic State in Iraq and Syria (ISIS) fired indiscriminately at four locations in the centre of Paris, killing 130 people. In a speech to the French National Assembly on 16 November, President François Hollande declared that France was at war and ordered a series of airstrikes on ISIS bases in Syria. Notably, Hollande invoked the EU's mutual-defence clause, Article 42(7) of the Treaty on European Union (TEU), which states that, if an EU Member State is the victim of armed aggression on its territory, the other Member States are obliged to render it all such assistance as lies within their power. In tones solemn and fateful, Hollande (2015, n.p.) stressed that 'the enemy is not just France's enemy, it is Europe's enemy. Europe cannot live in the belief that the crises around it have no effect on it'. The French president preferred to invoke Article 42(7) TEU rather than the solidarity clause, Article 222 TFEU, according to which the Union and its Member States are to act jointly in a spirit of solidarity in the event that a Member State is subjected to a terrorist attack, or falls victim to a natural or human-made disaster. This is the first time Article 42(7) TEU has been invoked, reflecting the view of the French government that the November attacks were an act of war and expresses its expectation that solidaristic military commitments on the part of France's fellow Member States would be forthcoming in the war against ISIS. All the EU Member States answered France's call for aid, but several stressed that the issue of military action against ISIS would have to be discussed separately. The UK chose to take part directly in bombing ISIS in Syria, and Germany assisted the action in question, underscoring the strong military solidarity that has emerged among the three largest countries in the Union. Unfortunately, several other large-scale terrorist attacks have occurred since November 2015: Brussels, Nice, and Berlin in 2016, followed by London, Stockholm, Paris, and Manchester in 2017. 
Against this background, the ability of Europeans to manage the many crises that have struck Europe in recent years stands out as crucial. For this reason, the focus of this book is on the dangers and perceptions thereof that beset Europe, and on the capacity of the Union and its Member States to meet them. This means taking a broad perspective on threats and perceptions thereof, while stressing their variety and complexity. (We make no claim, however, to any comprehensive coverage.) This book also draws attention to the quandary faced by the EU and national authorities as they try to reach balanced decisions about concrete measures in light of their long-term impact on society. Perhaps the greatest challenge in the current situation is the diversity of the dangers: some are based in a struggle for territorial domination; others have their sources in ideology and fanaticism; and still others arise as a consequence of society's technological, economic and social development.

The contributions to this book exhibit a thematic variation and an interdisciplinary approach that reflect the heterogeneity of both the security challenges facing the Union and the measures which must be taken to handle them. What do the current threats mean for the EU as a security community? What tools does the Union require to meet its security needs? How can it forestall long-term problems relating to food supply and economic growth? And what do the answers to these questions mean for the EU's fundamental values, for the rights of citizens both within the Union and elsewhere, and for the EU's relations with the outside world? These are just some of the questions addressed in this book.

\section{WILL THE EU SUSTAIN THE CHALLENGE POSED BY HEIGHTENED INSECURITY?}

The varied crises referred to above coincide more or less in time, and each poses a serious challenge to the Union. Their combined effect has been to strengthen doubts about the EU's ability to respond to security threats, to provide a platform for cooperation among its Member States in crisis management, and to function as a coherent actor on the global stage. Armed conflict and human hardship pose immediate problems, but their sources are complex. They are fuelled by poverty, authoritarian government, ongoing climate change, unequal economic development, and dismal prospects for rapidly growing numbers of youth. Never before has the Union faced so many threats of so diverse a character at the same time. However, it is important to remember that Europe has gone through major crises before. The basic idea behind integration is that cooperation is necessary to meet cross-border challenges. Among 
researchers, it is often held that a perceived need to deal with crises will lead to a greater willingness on the part of the EU Member States to compromise. Crises provide an incentive for unity and cooperation. Where solidarity in the current situation is concerned, however, the emergence of threats and crises has had ambiguous effects. On the one hand, the relatively far-reaching sanctions imposed in response to Russian policy in Ukraine have required common consent; moreover, Hollande's invocation of Article 42(7) TEU met with solidaristic backing for expanded military intervention in Syria. On the other hand, a different picture is presented by the EU's response to the euro crisis and the refugee crisis. The inability of the Member States to find common solutions to the latter problems has highlighted deep divisions within the EU regarding responsibility and solidarity, both within the Union and vis-à-vis the outside world.

Ultimately, this connects with an even deeper crisis that the EU is undergoing. The credibility of the Union as a security community is being called into question by citizens, by political parties, and by national governments of several EU Member States. At the same time, the EU's status as an international actor is meeting growing scepticism in the outside world. Not least, the political success of populist and anti-EU parties in several Member States, along with the perceived need in many countries for established parties to adapt to this situation, has given vent to widespread dissatisfaction with the EU as a political project. A widely noted example here is the UK, where Prime Minister David Cameron called a referendum in June 2016 on the country's continued EU membership, in a bid to stave off the pressure of longstanding anti-EU factions in the Conservative party. The fact that the referendum resulted in victory for the Leave-side underscores the challenges that the EU is facing to re-establish support among European populations. But political developments in countries such as Poland and Hungary, which have not only broken democratic values and norms, but have also consistently refused to honour the agreement to accept refugees, demonstrate the appeal of political selfishness. The European Commission's decision in December 2017 to trigger Article 7 of the Treaty of Lisbon, for the first time in the EU's history and in response to the Polish government's infringements of the independence of the country's judiciary, is indicative of an unprecedented rift between the EU's member states.

In this perspective, it is no exaggeration to say that the vision of the EU outlined in the Lisbon Treaty of 2009 is at stake. Views of the Union may be fundamentally changing, and the preparedness of its Member States to confront problems on a supranational basis may be declining. Political scientists tend to assume that crises pave the way for political change. The 
challenges the EU is facing could in fact result in a Union that is less supranational, yet also less legitimate and solidaristic.

The above-mentioned crises display great variation, both in their causes and in their effects. A traditional approach to security, mainly emphasizing the military capability of states to protect themselves against external aggression, prevailed during the Cold War. Since the 1990s, however, a broader concept of security has gained ground, which covers almost all conceivable threats to people as individuals. In 2003, the Commission on Human Security (2003, p. 4) defined 'human security' as involving the 'protect[ion of] the vital core of all human lives in ways that enhance human freedoms and human fulfilment'. In 2009, the United Nations Trust Fund for Human Security identified possible threats to such security as including (in addition to armed conflict and war) ill health, restrictions on access to food, economic dangers (for example, poverty and unemployment), climate change and environmental degradation, ethnic and religious violence, political repression and the violation of human rights, and violence arising from terrorism or from crime (United Nations, 2009, p. 6). In addition to broadening the range of threats to security to include those that apply from an individual human standpoint, the new approach has expanded on the traditional view of states as the principal actors in war and armed conflict. So-called asymmetric threats are now included too, where the adversary - which is not a unitary actor and which does not operate from a defined territory - applies unconventional methods such as terrorism and organized crime.

The threats facing the EU thus challenge the capacity of the state for defence and counterattack. For example, the terrorist attacks in Paris in 2015 and 2017 - like those against the editorial offices of Charlie Hebdo in Paris, and Krudttonden in Copenhagen, as well as the attacks in Nice, Berlin, London, Stockholm, and Manchester - represent a test of Europe's ability to respond to asymmetric threats. There is a danger, however, that heavy-handed measures will exacerbate the underlying problems, while the values that Europe means to defend are eroded. Efforts to tackle these threats also risk consigning the human dimension of the security question to the background. In a speech to the European Parliament on 25 November 2015, Jean-Claude Juncker, president of the European Commission, warned against 'equat[ing] refugees, asylum seekers, and migrants on the one hand with terrorists on the other'. After all, he pointed out, '[t]hose who carried out these attacks in Paris are the same people who are forcing the unhappy, the unlucky of this planet, to flee' (European Parliament, 2015). Hollande too highlighted, in his speech on 16 November the same year, the severe suffering of people in Syria and Iraq: '[P]articularly those living in territories controlled by Daesh 
... are the victims of this same terrorist system. That is why it is vital for Europe to offer a dignified welcome to those who are eligible for asylum' (Hollande, 2015, n.p.).

The horror aroused by the attacks in Paris in November 2015 could not fail to have an impact on EU policy towards the refugee crisis. A number of Member States had already responded to the latter by introducing stricter border controls, some of which have since remained in force. The resurrection of internal borders in the EU threatens to put an effective end to Schengen. The threat of terrorism within the Union has also brought to the fore, once again, a debate on the conflict between the need to protect society on the one hand, and the right of the individual to privacy, integrity, and freedom of thought on the other hand - a discussion highly topical since the terrorist attacks in the US on 11 September 2001. The Economist described this dilemma in an editorial on 21 November 2015, in which it reminded readers that 'the West has two things to defend: the lives of its citizens, and the liberal values of tolerance and the rule of law that underpin its society' (The Economist, 2015, n.p.).

This set of problems has emerged clearly in connection with the type of information warfare conducted both by ISIS and by Russia. The successful use by ISIS of social media to recruit disillusioned young people in European cities highlights vulnerabilities associated with unemployment, alienation, and inadequate integration. Russia, for its part, uses government-controlled media such as RT and Sputnik - along with Twitter, Facebook, and comment threads on the websites of European media - to present its preferred narrative on world politics. Aside from supporting the Russian version of events in Ukraine, this narrative aims - among other things through publication in local languages - to foment right-wing populist tendencies in EU Member States. The doomsday reporting on the refugee crisis by Russia's state-controlled media epitomizes this concern. EU citizens are confronted today with a highly relativized media environment, where news accessed through the Internet can be used to confirm just about every opinion on a political event. Both the EU and NATO have accordingly stressed the importance of countering Russia's information warfare, as well as the need to develop their own capacity for strategic communication.

We noted above the insufficient response of the EU and its Member States to the most acute crises. We underlined too the complexity of the threats and of perceptions thereof, as well as the difficulty of meeting the ongoing crises in a manner compatible with basic European values. Such pessimism could tempt us to fall back on national solutions, which in practice would mean a setback for European integration. That, however, would be an overly simple answer, especially since today's threats are 
eminently cross-border in character and so require coordinated solutions. Another aspect here - which may appear paradoxical - is that today's threats and crises have inspired Europeans to try to safeguard the freedoms which the EU has realized in terms of freedom of movement and the right to reside in other EU countries, as well as the economic opportunities afforded businesses and workers by the single market (the four freedoms). These gains have come to be taken for granted, but they are under challenge as witnessed not least in the British referendum in 2016. Certain groups and parties wish to reintroduce border controls, and to enact rules discriminating between a given country's citizens and other EU nationals.

Against this backdrop of a highly diverse set of security challenges currently facing the EU, the subsequent nine chapters of the book identify specific areas where these challenges stand out as crucial for the EU and suggest means for addressing them. An overview of the chapters follows.

\section{NINE ASPECTS OF THE CRISES FACING THE EU}

\section{How Can the Union Promote Security Community-building Beyond its Borders?}

In Chapter 2, 'The EU and the European security community: history and current challenges', Niklas Bremberg examines the EU's prospects for meeting the new security threats and risks. In an attempt to throw light on this matter, he considers the findings of research on the dynamics of regional 'security communities'. The EU is often seen as an example of a tightly bound security community. After all, the threat of war between different states has essentially disappeared from most of Europe. Moreover, the Union's unique mix of supranational and intergovernmental institutions makes it possible for its Member States to cooperate on addressing cross-border risks and non-military threats. What significance do today's threats and challenges have for maintaining, deepening or possibly dividing the European security community? Bremberg examines this question in view of the basic assumptions and main findings of the research on security communities, in view of the history of the European integration process, and in view of the emergence of EU capabilities for crisis management following the end of the Cold War. He then considers the Union's response to the Arab Spring of 2011 and to the ongoing refugee situation in the Mediterranean region in light of these theoretical and historical considerations. On the one hand, historically, the EU's response to crises reveals the deepening of security cooperation within the Union, which has been seen to this point as primarily crisis-driven. In many ways, crises 
that the EU has confronted during its integration process resemble those faced by the Union today. On the other hand, they also show how the inability to achieve joint solutions can lead to the disintegration of security communities.

On this basis, Bremberg presents three general recommendations for action that reflect the notion that the EU can best contribute to peace and security by encouraging security community-building practices both within and beyond its frontiers. Generally speaking, the Union should seek to strengthen cooperation on security challenges with other regional organizations, not least in the areas of conflict prevention and crisis management. The EU should also look at ways to make it easier for non-members to take part - by supporting their participation financially, for instance - in its military and civil efforts. Finally, the refugee situation in the Mediterranean highlights the increased need for rescue operations at sea. EU programmes for civil protection, Bremberg argues, should therefore be expanded to include such operations too, thereby strengthening the Union's humanitarian capacities.

\section{Conferring Voluntarily, and Promoting Peace Thereby}

In Chapter 3, 'After Lisbon: the new legal framework for the EU's Common Foreign and Security Policy', Inger Österdahl asks, from a juridical standpoint, how common is the EU's Common Foreign and Security Policy (CFSP)? She examines the extent to which the CFSP is 'juridified', that is, the importance of legal rules in shaping this policy. Generally speaking, the EU diverges from other cases of international cooperation in its unusually high degree of juridification and its particularly pronounced supranational features. The Union also stands out as a champion of international law at the global level. Österdahl stresses, however, that the policy process within the framework of the CFSP is not particularly juridified. Although recent judgments by the Court of Justice of the European Union (CJEU) open this to greater judicial involvement, the role of the EU Court in this area remains limited. Nor is the common foreign policy very common: each Member State is free, legally speaking, to conduct its own foreign policy parallel with that pursued by the Union. Moreover, all key decisions taken by the EU in this area require unanimity.

The lack of a strict legal framework poses no obstacle to the pursuit of a common policy, should Member States so wish. EU treaties neither require particular policies in this area nor set any substantive limits to policy coordination. There is thus a great deal of flexibility built into the CFSP that can be useful when the EU is faced with new security threats. But a common policy cannot be forced through by legal means. Instead, 
it must be based entirely on the political will of the Member States. In that sense, the Lisbon Treaty entailed no qualitative legal leap towards greater supranationalism in the area of foreign and security policy. Finally, Österdahl expresses the hope that the EU's Member States will continue their efforts to elaborate a common foreign and security policy. Such a policy would help the Union uphold its international position and make good on the values that form the basis for its own existence. Continuous interaction on foreign policy issues may also help - notwithstanding their sometimes controversial character - to strengthen cohesion within the Union and can be a good basis for cooperation with the UK after Brexit.

\section{Five Geo-economic Challenges for the EU in the Era of Sanctions}

In Chapter 4, 'Sanctions and the security policy environment from a European perspective', Mikael Eriksson analyses the Union as a global actor in the area of foreign and security policy, with a focus on the EU's use of targeted sanctions. He reviews how the EU has developed its sanctions instrument over time, and identifies some of the challenges to which this instrument is designed to respond. The use of sanctions by the Union, Eriksson argues, must be understood in a geo-economic perspective. Geo-economics refers here to the projection of power in the international system through a form of economic warfare. It involves affecting, undermining or subverting the power base of blacklisted actors. Eriksson shows how the EU has come to use sanctions as a means of leverage on the global stage. He devotes special attention to the shaping of the Union's geo-economic policy vis-à-vis Russia and Ukraine.

Eriksson's overall conclusion is that, while the EU has made good progress by converting geo-economic concepts into a sanctions instrument, several remaining challenges must be met if the effectiveness of this instrument is to be maximized. First and foremost, he argues, the purpose and effect of EU sanctions should be made clearer. The Union must show how sanctions serve to promote European peace and security. Second, the sanctions instrument must be systematically evaluated. Few researchers can say with scientific certainty that EU sanctions work satisfactorily, and this creates a credibility problem. Third, Eriksson further finds that sanctions ought to be designed in an overarching foreign policy context, and that the EU would benefit from clarifying the relation of sanctions to the CFSP and the Common Security and Defence Policy, and from striving to integrate these policy areas. In light of this, Eriksson believes the Union should enunciate a clearer European security doctrine on economic matters, in which sanctions can play a clear role. Finally, he argues that the EU sanctions policy should be monitored and evaluated in national parlia- 
ments. Policy in this area is formulated in Brussels, so there is otherwise a risk that crucial national dimensions will be neglected. Involving national parliaments in the conduct of sanctions policy will benefit the Union in the long term, as well as its Member States and their citizens. The EU as a peace project will be furthered as well.

\section{The EU's Ability to Meet the New Security Threats}

In Chapter 5, 'The EU's civilian crisis management capacity and the challenge of trust', Sten Widmalm, Thomas Persson, and Charles Parker assess the EU's ability to handle serious crises, and they consider some major challenges that the EU faces in this regard. The chapter starts with a review of some of the most important security threats the EU is experiencing today. The authors then describe the Union's crisis management mechanism and the new institutional framework in this area, which has emerged since the Lisbon Treaty. As a result of this framework, the Union has assumed an increasingly central role as a crisis manager in recent years. In addition, public opinion on the Union's capabilities in this area puts demands both on Member States and on the common institutions of the Union. The authors therefore discuss, with the help of data from the Eurobarometer, the high expectations that citizens in the Member States have regarding the EU's crisis management capabilities. However, while Member States have an obligation to assist in crisis situations, the rules in that regard tend to be set aside when unforeseen events such as the present refugee crisis arise. The authors show how the capacity to cooperate within and between Member States in such situations reflects how well individual decision-makers know each other, how much they trust one another, and whether they share norms and values. Another important issue is how well different administrative cultures interact and cooperate when events are moving rapidly.

The EU should continue, the authors conclude, to build up a common crisis management capacity, but this must be done carefully. Many of the crises the Union faces are cross-border in nature, requiring its Member States to help one another. As the three authors of this chapter see it, such cooperation cannot be based only on new institutional arrangements such as organs and agencies, regulatory frameworks, and general policies. A well-functioning system of cooperation is formed through good relations that build on trust, confidence, and common norms among the agencies entrusted with civil protection and crisis management. A wholly crucial question here, therefore, is whether it is possible to arrive at a common basic understanding on humanitarian issues through shared democratic values. As an ever greater number of extremist political parties enter 
parliament and government in EU Member States, the risk is that consensus on human dignity and democracy will be undermined. The authors stress that, without shared basic values to bind its different elements, the EU has bleak prospects as a crisis manager. Without a common view on democracy, the European project may fail.

\section{Addressing Substantial and Long-term Threats to Food Security}

In Chapter 6, 'Food security in Europe', Joakim Gullstrand and Christian Jörgensen describe developments over recent decades within the EU towards an increasingly secure food supply. They show how households' buffer against unexpected price increases has grown, as an ever smaller proportion of income is spent on food. Moreover, the supply of foodstuffs, seen in an historical perspective, is better than ever in terms of quantity, quality, and number of suppliers, due to technological advances and reductions in trade barriers. Notwithstanding these recent positive developments, however, the authors aver that the issue of food security remains highly topical. Demand for food is increasing due to global population growth, while future climate changes and shortages of fresh water may inhibit supply. In addition, food security can change dramatically over the short term in parts of Europe as a result of local conflicts or terrorist attacks, while price increases undermine food security for the most vulnerable.

As Gullstrand and Jörgensen point out, the EU already has structures that can be expanded in order to handle short-term problems of food supply. For example, the Union and its Member States can develop income-transfer systems to alleviate the situation of poor households faced with price increases. They can extend existing intergovernmental cooperation to deal with outbreaks of disease among farm animals. And they can improve stockpiles of food and of agricultural input products to deal with a temporary isolation. The authors regard such measures as far more effective than attempts to isolate Europe to increase food self-sufficiency, and much more fit for purpose than the imposition of temporary trade measures in order to influence price levels. The EU should instead continue to stimulate trade, so as to ensure better use of resources and more secure food supply for countries whose food production may be threatened by future climate change. Finally, the authors emphasize stimulating technological advances within agricultural production as an important means by which to ensure secure provision of foodstuffs for the future within the EU. For example, current policy within the Union inhibits the use of genetic engineering - a technology that has great potential for improving yields, water management, the 
nutritional content of food, and the cultivation of crops in less fertile soils.

\section{A More Rapid Pace of Innovation to Avert Threats Against Economic Growth}

In Chapter 7, 'The threats against innovation-based growth in the EU', Roger Svensson analyses threats to innovation-led growth in the EU. Many studies have shown new knowledge and technology to be the key factors of production for achieving growth. In a free market, however, spillover effects and incomplete capital markets lead to underinvestment in research and development (R\&D). In order to correct these market failures, the state can stimulate innovation and commercialization. It can do so by protecting intellectual property rights, and by supporting $\mathrm{R} \& \mathrm{D}$, innovation, and the training of R\&D personnel. If the EU cannot maintain a high rate of innovation, not just growth but also employment, the welfare of consumers, and the competitiveness of companies will be threatened. Svensson points out that the EU is lagging behind several major competitors (above all the US and Japan) when it comes to patent applications, private investment in $\mathrm{R} \& \mathrm{D}$, and the availability of $\mathrm{R} \& \mathrm{D}$ personnel, while China is rapidly catching up.

Serious efforts, according to Svensson, must be made in four areas to counter the threats and encourage innovation. Underinvestment in R\&D, due to spillover effects, is best remedied through tax incentives and direct state subsidies to $\mathrm{R} \& \mathrm{D}$. The latter should be focused on areas where spillover effects are high, particularly basic research and public needs. Svensson believes tax incentives should be increase-based, meaning that firms should receive more financing when their $R \& D$ investments are higher, while so-called patent boxes should be abolished. To deal with incomplete capital markets and the inadequate commercialization of new ideas, the state should concentrate support for innovation in the early stages, where it does the most good. Individuals can also be offered tax rebates to act as angel investors. Continued work on the standardized EU patent process is important for lowering the high cost of patents in Europe. Protection against infringement can be improved by state provision of legal support to smaller patent owners, and by enhanced international cooperation in prosecuting infringements of patents and copyright. Copyright periods, however, should be shortened considerably. Finally, Svensson argues, universities should continue to focus on basic research and the education of scholars. Research efficiency can be enhanced, however, by subjecting the allocation of research grants to greater competition and increasing the mobility of research personnel. More innovation can also be 
stimulated by sharing the ownership of research results between universities and researchers.

\section{An EU Law Compass for Data Security}

In Chapter 8, 'Threats to personal data security: how does the EU protect its citizens?', Cecilia Magnusson Sjöberg looks at threats to security that arise in connection with personal data and modern information and communications technology (ICT), and considers the challenges Europe faces when it comes to protecting privacy within digital networks that know no national borders. She describes the Internet as a catalyst in this trend, where social media such as Facebook and search engines such as Google often serve to exacerbate a difficult conflict: that between the individual's right to a personal sphere on the one hand, and the efforts of commercial interests and state surveillance agencies on the other. While encroachments on privacy can be legitimized to some extent by reference to security threats to society as such, the EU needs to protect its citizens against violations arising from inadequate safeguards in the handling of personal data.

Magnusson Sjöberg examines the EU's response to this development: the ongoing efforts to reform data protection, which have resulted in an entirely new Data Protection Regulation. The overall aim is to strengthen privacy protection. Rulings by the European Court of Justice confirming the right to be forgotten are important here, while transfers of personal data to countries outside the EU presuppose an adequate level of protection by the recipient country, particularly when it comes to safeguards for privacy. The need is plain, Magnusson Sjöberg argues, for a legal infrastructure that can counter today's threats to the privacy of personal data. She concludes that efforts to ensure trust and confidence in the daily use of ICT should continue, with EU law serving as a tool. Good examples are also needed of how methods for ensuring privacy can be woven together with legal decisions.

\section{Humanitarian Visas as the Liberal Test Case}

In Chapter 9, 'Security in a liberal union: EU asylum and migration control policies', Gregor Noll relates the book's theme of new security threats to the current issue of the EU's handling of refugees and asylum-seekers. According to Noll, EU policy on questions of immigration and asylum ultimately constitutes a protectionist regime, with its starting point in the control needs of the nation-state. Indeed, this regime was already manifest at the Union's inception in the 1950s. The current rules on immigration and asylum can thus be seen as a product of nation-state protectionism, 
which in a paradoxical way was strengthened during the crisis year of 2015 . Noll argues too that the concept of solidarity enunciated in the Treaty on the Functioning of the European Union is wrongly designed, because it is subordinated to the protectionist regime.

Noll then charts several possible options, starting from the assumption that the Union cannot - if it takes its liberal identity seriously - deny the rationality and free will of the asylum-seeker. The question is whether today's protectionist system can be complemented with a recognition of the asylum-seeker's free will, without at the same time putting utopian or revolutionary demands on the EU in its current form. The author tests a number of ideas for reform against a collection of legal and political criteria, and argues that issuing humanitarian visas at Member States' missions abroad can complement the EU's asylum policy in a way that satisfies both these imperatives. In such a system, the asylum-seeker and the Member State meet in a rational dialogue early on - before the asylum-seeker chooses to embark on the journey to Europe. Noll concludes that four measures are necessary to increase the element of solidarity in EU policy on immigration and asylum. The Dublin Regulation should be abolished, and the rights of asylum-seekers must be guaranteed in practice and not just in theory. It is further necessary that the enforcement of these rights be overseen - in a higher degree than at present - by courts and other monitoring bodies. Finally, a subset of the Union's Member States should introduce a common system for issuing humanitarian visas, making legal entry possible for persons who meet the system's criteria.

\section{Stimulate Debate, Share Responsibility, Think Long Term and Think Anew}

In Chapter 10, 'Europe: take on your responsibilities', Charlotte Wagnsson asks whether Europe is taking sufficient responsibility for contemporary threats to security. Scholars and politicians increasingly link security with the taking of responsibility, which in turn can reflect both altruistic considerations and national interests. As Wagnsson sees it, it falls more and more on the EU and its Member States to take responsibility, because the dangers are escalating and the US is weakening as a superpower. The pursuit of status in the international system and the need to deal with perceived threats are key motivations for states and other international actors to take responsibility. But for which threats is the Union willing to take responsibility, and what quantity of resources is it prepared to devote to dealing with them? To answer these questions, Wagnsson examines public opinion, political will, and defence spending in the EU, with a particular focus on 'the big three': the UK, Germany, and France.

Europeans, Wagnsson shows, are increasingly worried about threats to 
security, and they view the threats springing from terrorism and religious extremism as the most serious ones. Russia's behaviour is another source of concern. Perceptions of the nature and source of threats vary. In southern Europe, people tend to focus on dangers in the Middle East and around the Mediterranean. In northern and eastern Europe, by contrast, Russia is perceived as the primary danger. But the differences are not significant, and the most influential countries are prepared to deal with problems in both the east and the south. In general, moreover, the willingness of EU Member States to increase defence spending has also increased somewhat. But from a military point of view - and from an American perspective especially - Europe still is not taking enough responsibility. This view has been made blatantly clear after the election of Donald J. Trump as president. Wagnsson points out, however, that strengthening military forces is not the only way to shoulder responsibility. She concludes with a number of recommendations. First, responsibility must be shared among different actors and policy areas. Second, measures should be taken to convince the public of the need to take greater responsibility. This can mean holding national debates on the subject, publicizing strategic documents, etc. Third, taking responsibility in the short term is not the only thing: working out long-term strategies and methods of prevention is necessary too. Nontraditional strategies can also be important: for example, involving women in peace processes and the handling of propaganda. The last-mentioned activity has to do with how security situations are represented and interpreted; it concerns the struggle over perceptions of reality. This is a struggle that is becoming ever more important, at a time when images and messages are spread instantly through social media.

\section{WHAT CAN BE DONE TO CURB THE THREATS?}

What, then, can the Union and its Member States concretely do to curb threats and perceptions thereof, and to mitigate the impact of today's crises? One obvious measure involves strengthening solidarity among the Member States, both in terms of traditional territorial security and in regard to the reception of refugees. This will necessitate an overhaul of asylum policy, as well as practical measures to support the countries most immediately affected by the tide of refugees. Another type of solidarity concerns foreign and security policy. Member States need to realize that European positions only have an impact at the international level when they are presented with a single voice. In addition, better cooperation between judicial bodies and national security services must be given the highest priority. The opportunities for coordination that already exist to 
combat terrorism and religious radicalism within the Union must likewise be utilized fully.

The Union cannot achieve legitimacy unless citizens feel that its policies and actions serve to improve their lives economically, socially, culturally, and in terms of security. The EU's institutions and its Member States must therefore give priority to upholding the four freedoms, the importance of which will only increase after Brexit. Among these, those bearing on economic and social conditions stand out as particularly important from a security perspective. Economic growth and social security are fundamental for cohesion and solidarity among the Union's Member States. Interdependence is far-reaching among these states, as well as between them and the Union's institutions. No single country can overcome the challenges it faces. Nor can the EU's institutions conduct any common policy unless the Member States support it and participate in its making. This circumstance alone yields powerful incentives for EU policy-makers to get the better of threats and to move matters in a positive direction. At the same time, however, they must safeguard mutual trust and solidarity.

\section{REFERENCES}

Beck, U. (1992), Risk Society: Towards a New Modernity, London: Sage. Commission on Human Security (2003), Human Security Now, New York: CHS. European Parliament (2015), 'Don't equate refugees with terrorists - boost security instead, urge MEPs', Press release, Justice and Home Affairs, 25 November, accessed 9 May 2017 at http://www.europarl.europa.eu/news/en/news-room/20151120IPR0 $3639 / \mathrm{Don}^{2} \mathrm{E} 2 \% 80 \% 99$ t-equate-refugees-with-terrorists- $\% \mathrm{E} 2 \% 80 \% 93$-boost-secu rity-instead-urge-MEPs.

Giddens, A. (1990), The Consequences of Modernity, Stanford: Stanford University Press.

Hollande, F. (2015), 'Speech by the President of the Republic before a joint session of Parliament', France Diplomatie, 16 November, accessed 9 May 2017 at http://www. diplomatie.gouv.fr/en/french-foreign-policy/defence-security/parisattacks-paris-te rror-attacks-november-2015/article/speech-by-the-president-of-the-republic-befo re-a-joint-session-of-parliament.

The Economist (2015), 'How to fight back: The battle against Islamic State must be waged on every front', 21 November, accessed on 9 May 2017 at http://www. economist.com/news/leaders/21678785-battle-against-islamic-state-must-be-wa ged-every-front-how-fight-back.

United Nations (2009), Human Security in Theory and Practice: An Overview of the Human Security Concept and the United Nations Trust Fund for Human Security, New York: United Nations. 